\title{
Eyelid Carcinoma pN0 TNM Finding v8
}

National Cancer Institute

\section{Source}

National Cancer Institute. Eyelid Carcinoma pNO TNM Finding v8. NCI Thesaurus. Code C140506.

Eyelid carcinoma with no evidence of lymph node involvement. (from AJCC 8th Ed.) 